\title{
Assessment of the nurses' work environment using the nursing work index scale
}

\section{Hemşirelerin çalışma ortamının hemşirelik iş indeksi ölçeğine göre değerlendirilmesi}

Hatice Ulusoy ${ }^{1}$, Reyhan Polatkan ${ }^{2}$

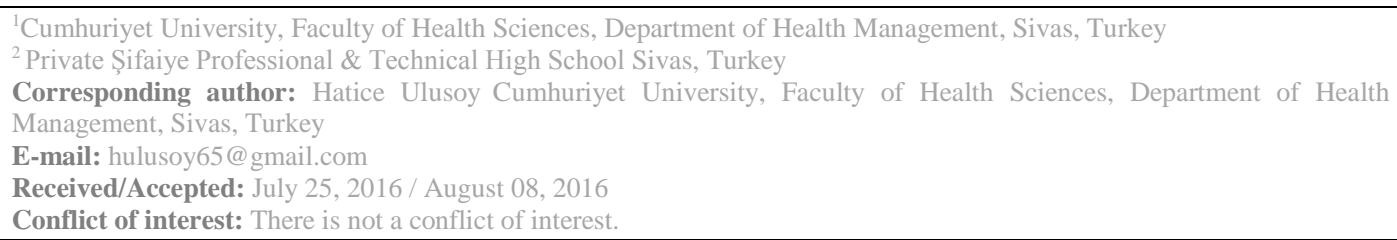

\section{SUMMARY}

Objective: One of the major reasons for the increase in nurse turnover rate in hospitals is the nurses' negative work environment. The negativity of the work environment reduces nurses' performance and adversely affects the quality of patient care and patient and health care workers safety. This present study was conducted to determine nurses' assessment of the work environments.

Method: In this cross-sectional study, the study sample comprised 174 nurses who worked in Cumhuriyet University Hospital between October - November 2014, agreed to participate in the study and filled in the data collection forms completely. Data were collected with the sociodemographic characteristics questionnaire and the "Nursing Work Index- the Practice Environment Scale".

Results: The mean age of the participating nurses was 32.09 \pm 7:09. Of them, $86.8 \%$ were women, $64.9 \%$ were married, $74.7 \%$ had a graduate degree, $84.5 \%$ were permanently employed, $32.2 \%$ had a working experience in the profession less than 5 years and $79.9 \%$ were the members of a union or association. The total mean score obtained from the scale was $X=2.16 \pm 0.49$. Of the participants in the study, those who were male, contractual employees and/or members of a professional organization and whose length of service was under 5 years perceived their work environment more positively ( $\mathrm{p}<0.05$ ). No statistically significant relationship was determined between the total scores and variables 'age, education level, professional title, and average monthly income level' ( $p>0.05)$. Conclusions: It was found that the participating nurses assessed the work environment as moderately whereas they perceived the "adequacy of manpower and other resources" subscale negatively.

Keywords: nursing, nursing work environment, patient \& healthcare workers safety

\section{ÖZET}

Amaç: Hastanelerde hemşire devir hızının artmasının önemli nedenlerinden birisi hemşirelerin çalışma ortamlarının olumsuz olmasıdır. Çalışma ortamlarının olumsuzluğu ise hemşirelerin performansını azaltmakta, hasta bakım kalitesini ve hasta ve çalışan güvenliğini olumsuz etkilemektedir. Bu araştırma, hemşirelerin çalışma ortamına ilişkin değerlendirmelerini belirlemek amacıyla yapılmıştır.

Yöntem: Kesitsel olarak yapılan bu çalışmanın örneklemini Ekim-Kasım 2014 tarihleri arasında Cumhuriyet Üniversitesi Hastanesinde görev yapan, çalışmaya katılmayı kabul eden ve veri toplama 
formlarını eksiksiz dolduran 174 hemşire oluşturmuştur. Veriler kişisel bilgi formu ve "Hemşirelik İş İndeksi-Hemşirelik Çalışma Ortamını Değerlendirme Ölçeği” kullanılarak toplanmıştır.

Bulgular: Hemșirelerin yaș ortalaması 32.09 7.09 olup, \%86.8'i kadın, \% 64.9 evli \% 74.7'i lisans mezunu, \%84.5'si kadrolu, \% 32,2 sinin meslekteki çalıșma deneyimi 5 yıl ve altındadır. Hemşirelerin \% 79,9 bir sendika veya derneğe üyedir. Ölçekten alınan toplam puan ortalaması $\mathrm{X}=2,16 \pm 0,49$ olarak saptanmıştır. Çalışmada erkeklerin, sözleşmeli çalışanların, bir derneğe veya sendikaya üye olanların ve çalıșma yılı 5 yılın altında olanların hemșirelik çalıșma ortamına yönelik tutumlarının daha olumlu olduğu belirlenmiş̧tir $(\mathrm{p}<0.005)$.Yaş, öğrenim durumu, profesyonel ünvan, aylık gelir ile toplam puan ortalaması arasında istatistiksel olarak anlamlı bir fark saptanmamıştır $(\mathrm{p}>0.005)$

Sonuç: Hemşirelerin çalışma ortamını genel olarak orta düzeyde değerlendirdiği ancak "insan gücü ve diğer kaynakların yeterliliği" alt boyutunu olumsuz değerlendirdikleri saptanmıştır.

Anahtar Sözcükler: Hemşirelik, hemşirelik çalışma ortamı, hasta ve sağlık çalışanı güvenliği

\section{INTRODUCTION}

Working life has an important place in human life. Throughout human history, work and working individuals have been praised in all societies. Work is defined as the production of goods and services which have the use and exchange value, and consists of production activities in relation to the production of all kinds in any working environment. The main components of production are the labor force, production tools and work environment. ${ }^{1}$ Work life not only provides an individual with a certain role, social prestige and economic benefits within the community, but also brings about certain psychological and psychosocial problems. ${ }^{2}$

Work environment, in which the most active period of the day is spent, can affect physical, mental and social health due to dissatisfactions, accidents and risks which can destroy workers' health. ${ }^{3}$ The International Council of Nurses (ICN) which is the world's first and largest health organization representing more than 13 million health care professionals in 129 countries defines the positive work environment as "settings that support excellence and decent work, ensure the health, safety and personal well-being of staff, support quality patient care and improve the motivation, productivity and performance of individuals and organizations". ${ }^{4}$

Nursing profession is a stressful occupation and has a heavy workload. Many negative factors stemming from the work environment affect it. ${ }^{2}$ Problems nurses face in the work environment have negative physical, psychological and social effects on them. It is important that nurses who provide healthcare to other people should be in a perfect state of well- being and that this state of well-being should be maintained. ${ }^{5}$ Therefore, the perception of nurses' work environments and working conditions, and taking corrective measures when necessary are of great importance. ${ }^{6}$ Of the factors that negatively affect the working conditions of nurses, the leading one is the heavy workload due to the large number of patients and the small number of nurses. Studies on the issue report that in hospitals with a shortage of nurses, nurses suffer job dissatisfaction more and have high levels of burnout ${ }^{4}$, that the quality of patient care and thus patient safety is low and that mortality rates are high. ${ }^{7-11}$ Factors such as distress caused by the nature of the profession and the excessive workload, long working hours, communication problems, interpersonal conflicts, high levels of risks and dangers in the workplace, and the risk of exposure to violence by patients and patients' relatives are also considered among the factors affecting the environment negatively.,12 Nursing also includes stress-related risk factors such as carrying out difficult and complex tasks, inadequate rest breaks, monotony and physically unfavorable working conditions (i.e. location, temperature and lighting). In addition, during routine applications, nurses face problems such as having to stand for long periods 
depending on the intensity of the workload, having to work in shifts, and having to have meals at irregular times. 13,14

According to the International Labor Organization (ILO), major stressors of the work environment affecting nurses are conflicts with managers, role conflict and ambiguity, excessive workload, emotional stress experienced due to dealing with patients especially with patients in need of intensive care or dying patients, interpersonal conflicts and shift work. ${ }^{15}$ In several studies, among the factors adversely affecting the work environment are having to do things other than occupational tasks ${ }^{16}$, low level of professional reputation and lack of motivation. ${ }^{17,18}$

In order to work effectively, nurses need a work environment which supports their professional nursing practices because the work environment has a crucial impact on the delivering quality care and ensuring patient and staff safety. ${ }^{4,19}$ In addition to the problems inherent in the profession, adverse working conditions lead to job dissatisfaction and burnout among nurses, which increases intention to leave and thus nurse turnover rates, reluctance in dealing with patient care and tendency to work in jobs other than nursing. ${ }^{20-23}$

In almost every country, most of the healthcare is provided by nurses. Nursing shortage is experienced globally and is one of the major factors which hinder the achievement of the objectives of health services. The ICN has offered five main proposals to solve the nursing shortage problem that threatens health services. One of these proposals is to provide a positive work environment for nurses.

Many studies report that a nurse's "intention to leave the profession" (whether he/she leaves or not) is an indication of the nurses' job dissatisfaction., ${ }^{4,20,21,23-25}$ One of the main causes of increases in job dissatisfaction and nurse turnover rates, and decreases in the number of nurses in hospitals is nurses' negative work environments. ${ }^{4,11}$ According to the data released by the Turkish Nurses Association (TNA), one out of every five nurses is planning to leave the profession within the next five years. A nurse's resignation from work means an increase in nursing shortage, leading to a vicious cycle which affects other nurses' job satisfaction in the workplace adversely and increases their intention to leave the profession (TNA 2008). ${ }^{22}$ Indeed, in a study conducted to investigate the nurse turnover rate in Cumhuriyet University hospital, the nurse turnover rate was calculated as 19.4 , and $42 \%$ of the nurses had an intention to leave the workplace..$^{25}$

There are positive work environments which support high performance in nursing, and attract and attach nurses to the profession. Positive work environment has many beneficial effects such as protection and maintenance of nurses' health, enhancement of the quality and performance of the patient care, and ensuring patient and staff safety. ${ }^{4,9}$

Given the countrywide effects of a positive work environment, a positive work environment is the prerequisite for work performance and rapid and healthy development. ${ }^{26}$ Nurses deserve a work environment which offers them an organizational and human support so that they can provide safe, adequate and skilled nursing care. ${ }^{11,27-29}$ As stated in the "Notification on the Procedures and Principles to Ensure and Protect the Safety of the Patient and Staff at Health Institutions and Organizations" released by the Ministry of Health of Republic of Turkey on April 29, 2009, hospitals are obliged to provide a safe work environment for employees and take measures to reduce the risks associated with healthcare workers safety. ${ }^{30}$

Today, working in a healthy and safe work environment is a human right that every employee has, and all organizations including hospitals must comply with the laws related to this issue. 30 As stated above, the presence or absence of a positive work environment in an institution is one of the factors that significantly affect employees' job performance, work motivation, job satisfaction and physical and psychosocial health, patient and healthcare workers safety and ultimately both the quality of services offered by the organization and the organization itself. 
4,27,31 Therefore, it is important to evaluate the work environment in accordance with nurses' perception. This present study was conducted to determine nurses' assessment of nursing work environment.

\section{MATERIAL AND METHODS}

The target population of this descriptive cross-sectional study comprised 453 nurses who worked in Cumhuriyet University Hospital between October 30, 2014 and November 5, 2014. Without any sample selection, the entire population was aimed to reach. Of the nurses in the target population, 174 $(38,4 \%)$ who agreed to participate in the study and filled in the data collection forms completely were included in the study.

\section{Data Collection Tools:}

1. Sociodemographic characteristics questionnaire: This form included eight items questioning the participants' sociodemographic characteristic such as gender, age, marital status, education level.

2. Nursing Work Index- The Practice Environment Scale: The scale was developed by Lake in the USA ${ }^{32}$. The scale includes 31 items and 5 subscales. Turkish validity and reliability study of the scale was conducted Türkmen et al. ${ }^{21}$ It is a 4-point Likert-type scale scored as 4 = Strongly Disagree, $3=$ Disagree Agree, $2=$ Agree and $1=$ Strongly Agree . As the scores the participants obtain from the scale increase, so do their positive attitudes towards their work environment. The lowest and highest possible scores to be obtained from the scale were 31 and 124 respectively. While lower mean scores obtained from the whole scale and subscales indicate negative perceptions of the work environment, higher mean scores indicate positive perceptions of the work environment.
Subscales and items of the scale

The first subscale: nurses' participation and representation rate in the management: items 5, 6, 11, 15, 17, 21, 23, 27 and 28.

The second subscale: nursing foundations needed for quality care: items 4, 14, 18, 19, 22, 25, 26, 29, 30 and 31.

The third subscale: Nurse Managers' attitudes and leadership traits: items 3, 7, 10,13 and 20.

The fourth subscale: Adequacy of staff (work force) and other resources: items 1, 8,9 and 12 .

The fifth subscale: Communication between physicians and nurses: items 2 , 16 and 24.

The data were analyzed using the SPSS 14.0. To analyze the data, percentages, means, Mann-Whitney U-test, t-test and Kruskal-Wallis test were used. The statistical significance was established at a p value $<0.05$.

\section{Implementation of the Study and Ethical Issues:}

The study was conducted with the permission (dated and numbered 01.15.2015 and 2015-01 / 04 respectively) of the Non-interventional Clinical Research Ethics Committee of Cumhuriyet University. In addition, written permission was obtained from the Cumhuriyet University Hospital Administration (Hospital Director, Director-General's Office and Head Nursing Office) through the request of the Cumhuriyet University Presidency.

The data were collected from the participants through face-to-face interviews with the survey forms. The participants were told that participation was voluntary, that they were requested not to write their credentials on the questionnaires, that the study data would be used only within the scope of this study and that their privacy would certainly be protected. 


\section{RESULTS}

Table 1. Distribution of participating nurses in terms of their sociodemographic characteristics $(\mathbf{N}=\mathbf{1 7 4})$

\begin{tabular}{|l|c|c|}
\hline & $\mathbf{N}$ & $\mathbf{\%}$ \\
\hline GENDER & & \\
\hline Female & 151 & $\mathbf{8 6 . 8}$ \\
\hline Male & 23 & 13.2 \\
\hline MARITAL STATUS & & \\
\hline Married & 113 & $\mathbf{6 4 . 9}$ \\
\hline Single & 61 & 35.1 \\
\hline EDUCATION & 14 & \\
\hline High school & 13 & 7.5 \\
\hline Associate degree & 130 & $\mathbf{7 4 . 7}$ \\
\hline BSc & 17 & 9.8 \\
\hline MSc & & \\
\hline EMPLOYMENT STATUS & 147 & $\mathbf{8 4 . 5}$ \\
\hline Permanent & 27 & 15.5 \\
\hline Contractual & & \\
\hline MEMBER OF A UNION OR ASSOCIATION? & 139 & $\mathbf{7 9 . 9}$ \\
\hline Yes & 35 & 20.1 \\
\hline No & & \\
\hline LENGTH OF SERVICE & 56 & $\mathbf{3 2 . 2}$ \\
\hline$\leq 5$ years & 37 & 21.3 \\
\hline $6-10$ years & 32 & 18.4 \\
\hline $11-15$ years & 29 & 11.5 \\
\hline $16-20$ years & 20 & 16.6 \\
\hline$\geq 21$ years & & \\
\hline MONTHLY INCOME & 10 & 5.7 \\
\hline$\$ 500-700$ & 129 & $\mathbf{7 4 . 1}$ \\
\hline$\$ 701-850$ & 5 & 2.9 \\
\hline$\$ 851-1000$ & 19 & 10.9 \\
\hline$\$ 1001-1300$ & 11 & 6.3 \\
\hline$\geq \$ 1301$ & & \\
\hline & & \\
\hline
\end{tabular}

The mean age of the participating nurses was $32.09 \pm 7: 09$. Of them, $86.8 \%$ were women, $64.9 \%$ were married, $74.7 \%$ had a graduate degree, $84.5 \%$ were permanent employees, $32.2 \%$ had a working experience in the profession less than 5 years, $79.9 \%$ were members of a union or association, and $74.1 \%$ had a monthly income between $\$ 701$ and $\$ 850$.

Table 2. Distribution of the mean total and mean subscale scores $(N=174)$

\begin{tabular}{|c|c|c|c|}
\hline Subscale & $\mathbf{( X \pm \text { Sd) }}$ & Min & Max. \\
\hline $\begin{array}{l}\text { 1. Nurses' participation and representation rate in the } \\
\text { management }\end{array}$ & $2.20 \pm 0,57$ & 1 & 3.67 \\
\hline 2. Nursing foundations needed for quality care & $\mathbf{2 . 3 6} \pm \mathbf{0 , 5 6}$ & 1 & 3.40 \\
\hline 3. Nurse Managers' attitudes and leadership traits & $2.34 \pm 0,70$ & 1 & 3.60 \\
\hline 4. Adequacy of staff and other resources & $\mathbf{1 . 5 4} \pm \mathbf{0 , 4 7}$ & 1 & 3.25 \\
\hline 5. Communication between physicians and nurses & $2.34 \pm 0,70$ & 1 & 4 \\
\hline Total Score of the Scale & $\mathbf{2 . 1 6} \pm \mathbf{0 , 4 9}$ & $\mathbf{1}$ & $\mathbf{3 . 3 1}$ \\
\hline
\end{tabular}

In Table 2, the distribution of the mean total score and mean subscale scores are given. While the highest mean score $(\mathrm{X}=$
$2.36 \pm 0.56$ ) was obtained from the "nursing foundations needed for quality care" subscale, the lowest score 
$(\mathrm{X}=1.54 \pm 0.47)$ was obtained from the "Adequacy workforce and other resources" subscale. The total mean score obtained from the scale (out of 4 points) was determined as $\mathrm{X}=2.16 \pm 0.49$.

Given that high scores obtained from the scale indicate that participants have positive perceptions of the work environment and subscales, the perceptions of the nurses who participated in the present study regarding the work environment were "moderately".

Table 3. Distribution of the mean total and mean subscale scores in terms of the participants' genders

\begin{tabular}{|c|c|c|c|c|c|c|}
\hline Subscales & Gender & $\mathrm{N}$ & Mean & SS & $\mathrm{t}$ & $\mathrm{p}$ \\
\hline \multirow{2}{*}{$\begin{array}{l}\text { 1. nurses' participation and } \\
\text { representation rate in the } \\
\text { management }\end{array}$} & $\mathrm{F}$ & 151 & 2.18 & 0.598 & \multirow[b]{2}{*}{-1.734} & \multirow[b]{2}{*}{0.085} \\
\hline & M & 23 & 2.40 & 0.295 & & \\
\hline \multirow{2}{*}{$\begin{array}{l}\text { 2. nursing foundations } \\
\text { needed for quality care } *\end{array}$} & $\mathrm{~F}$ & 151 & 2.32 & 0.571 & \multirow{2}{*}{-2.315} & \multirow{2}{*}{0.022} \\
\hline & $\mathrm{M}$ & 23 & 2.61 & 0.444 & & \\
\hline \multirow{2}{*}{$\begin{array}{l}\text { 3. Nurse Managers' } \\
\text { attitudes and leadership } \\
\text { traits }\end{array}$} & $\mathrm{F}$ & 151 & 2.30 & 0.698 & \multirow[b]{2}{*}{-1.589} & \multirow[b]{2}{*}{0.114} \\
\hline & M & 23 & 2.55 & 0.687 & & \\
\hline \multirow{2}{*}{$\begin{array}{l}\text { 4. Adequacy of workforce } \\
\text { and other resources * }\end{array}$} & $\mathrm{F}$ & 151 & 1.51 & 0.468 & \multirow{2}{*}{-2.577} & \multirow{2}{*}{0.011} \\
\hline & $\mathrm{M}$ & 23 & 1.78 & 0.454 & & \\
\hline \multirow{2}{*}{$\begin{array}{l}\text { 5. Communication between } \\
\text { physicians and nurses }\end{array}$} & $\mathrm{F}$ & 151 & 2.31 & 0.724 & \multirow{2}{*}{-1.830} & \multirow{2}{*}{0.069} \\
\hline & $\mathrm{M}$ & 23 & 2.59 & 0.460 & & \\
\hline \multirow{2}{*}{ Total Score of the Scale * } & $\mathrm{F}$ & 151 & 2.12 & 0.509 & \multirow{2}{*}{-2.394} & \multirow{2}{*}{0.018} \\
\hline & $\mathrm{M}$ & 23 & 2.39 & 0.328 & & \\
\hline
\end{tabular}

* Statistically significant

As is seen Table 3 , according to the mean scores obtained both from the entire scale and from the subscales, male participants perceived the work environment more positively than did the female participants. There was a statistically significant relationship between the gender variable and the mean scores obtained from the whole scale and second and fourth subscales $(\mathrm{p}<0.05)$.

Table 4. Distribution of the mean total and subscale scores in terms of being a member of a union or association

\begin{tabular}{|c|c|c|c|c|c|c|}
\hline Subscales & Member? & $\mathbf{N}$ & Mean & SS & $\mathbf{t}$ & $\mathbf{p}$ \\
\hline \multirow{2}{*}{$\begin{array}{l}\text { 1. Nurses' participation } \\
\text { and representation rate } \\
\text { in the management* }\end{array}$} & No & 35 & 1.93 & 0.653 & \multirow[b]{2}{*}{-3.243} & \multirow[b]{2}{*}{0.001} \\
\hline & Yes & 139 & 2.27 & 0.530 & & \\
\hline \multirow{2}{*}{$\begin{array}{l}\text { 2. Nursing foundations } \\
\text { needed for quality care } \\
*\end{array}$} & No & 35 & 2.02 & 0.689 & \multirow[b]{2}{*}{-4.213} & \multirow[b]{2}{*}{0.000} \\
\hline & Yes & 139 & 2.44 & 0.493 & & \\
\hline \multirow{2}{*}{$\begin{array}{l}\text { 3. Nurse Managers' } \\
\text { attitudes and leadership } \\
\text { traits* }\end{array}$} & No & 35 & 2.01 & 0.855 & \multirow[b]{2}{*}{-3.143} & \multirow[b]{2}{*}{0.002} \\
\hline & Yes & 139 & 2.42 & 0.632 & & \\
\hline \multirow{2}{*}{$\begin{array}{l}\text { 4. Adequacy of workforce } \\
\text { and other resources }\end{array}$} & $\mathrm{No}$ & 35 & 1.54 & 0.512 & \multirow{2}{*}{-.083} & \multirow{2}{*}{0.934} \\
\hline & Yes & 139 & 1.55 & 0.466 & & \\
\hline \multirow{2}{*}{$\begin{array}{l}\text { 5. Communication } \\
\text { between physicians and } \\
\text { nurses* }\end{array}$} & No & 35 & 2.09 & 0.782 & \multirow[b]{2}{*}{-2.408} & \multirow[b]{2}{*}{0.017} \\
\hline & Yes & 139 & 2.41 & 0.667 & & \\
\hline \multirow{2}{*}{ Total Score of the Scale * } & No & 35 & 1.92 & 0.620 & \multirow{2}{*}{-3.283} & \multirow{2}{*}{0.001} \\
\hline & Yes & 139 & 2.22 & 0.442 & & \\
\hline
\end{tabular}

* Statistically significant 
As is seen Table 4, according to the mean scores obtained both from the entire scale and from the subscales, participants who were members of a union or association perceived the work environment more positively than did those who were not.
There was a statistically significant relationship between the variable 'being a member of a union or association' and the mean scores obtained from the whole scale and subscales except for the fourth subscale $(\mathrm{p}<0.05)$.

Table 5. Distribution of the mean total and mean subscale scores in terms of being a permanent or contractual employee

\begin{tabular}{|c|c|c|c|c|c|c|}
\hline Subscales & $\begin{array}{l}\text { Employment } \\
\text { status }\end{array}$ & $\mathbf{N}$ & Mean & SS & $\mathbf{t}$ & $\mathbf{p}$ \\
\hline \multirow{2}{*}{$\begin{array}{l}\text { 1. Nurses' participation } \\
\text { and representation } \\
\text { rate in the } \\
\text { management }\end{array}$} & Permanent & 147 & 2.19 & 0.598 & \multirow[b]{2}{*}{-1.103} & \multirow[b]{2}{*}{0.271} \\
\hline & Contractual & 27 & 2.32 & 0.393 & & \\
\hline \multirow{2}{*}{$\begin{array}{l}\text { 2. Nursing foundations } \\
\text { needed for quality } \\
\text { care } *\end{array}$} & Permanent & 147 & 2.32 & 0.578 & \multirow[b]{2}{*}{-2.608} & \multirow[b]{2}{*}{0.010} \\
\hline & Contractual & 27 & 2.62 & 0.396 & & \\
\hline \multirow{2}{*}{$\begin{array}{l}\text { 3. Nurse Managers' } \\
\text { attitudes and } \\
\text { leadership traits* }\end{array}$} & Permanent & 147 & 2.28 & 0.679 & \multirow[b]{2}{*}{-2.736} & \multirow[b]{2}{*}{0.007} \\
\hline & Contractual & 27 & 2.67 & 0.734 & & \\
\hline \multirow{2}{*}{$\begin{array}{l}\text { 4. Adequacy of } \\
\text { workforce and other } \\
\text { resources }\end{array}$} & Permanent & 147 & 1.55 & 0.485 & \multirow[b]{2}{*}{-.190} & \multirow[b]{2}{*}{0.850} \\
\hline & Contractual & 27 & 1.56 & 0.419 & & \\
\hline \multirow{2}{*}{$\begin{array}{l}\text { 5. Communication } \\
\text { between physicians } \\
\text { and nurses }\end{array}$} & Permanent & 147 & 2.30 & 0.703 & \multirow[b]{2}{*}{-1.898} & \multirow[b]{2}{*}{0.059} \\
\hline & Contractual & 27 & 2.58 & 0.651 & & \\
\hline \multirow{2}{*}{$\begin{array}{l}\text { Total Score of the } \\
\text { Scale * }\end{array}$} & Permanent & 147 & 2.13 & 0.506 & \multirow{2}{*}{-2.187} & \multirow{2}{*}{0.030} \\
\hline & Contractual & 27 & 2.35 & 0.394 & & \\
\hline
\end{tabular}

* Statistically significant

In Table 5, the distribution of the mean total score and mean subscale scores in terms of being a permanent or contractual employee are given. As is seen Table 5, according to the mean scores obtained both from the entire scale and from the subscales, of the participants, who were contractual employees perceived the work environment more positively than did those who were permanent employees.

There was a statistically significant relationship between the 'employment status' variable and the mean scores obtained from the whole scale and second and third subscales $(\mathrm{p}<0.05)$. 
Table 6. Distribution of the mean total and mean subscale scores in terms of length of service.

\begin{tabular}{|c|c|c|c|c|c|c|}
\hline & $\begin{array}{c}\text { 1. nurses' } \\
\text { participation } \\
\text { and } \\
\text { representation } \\
\text { rate in the } \\
\text { management } \\
\end{array}$ & $\begin{array}{c}\text { 2. nursing } \\
\text { foundations } \\
\text { needed for } \\
\text { quality } \\
\text { care* }\end{array}$ & $\begin{array}{c}\text { 3. Nurse } \\
\text { Managers' } \\
\text { attitudes and } \\
\text { leadership } \\
\text { traits* }\end{array}$ & $\begin{array}{l}\text { 4. Adequacy } \\
\text { of workforce } \\
\text { and other } \\
\text { resources }\end{array}$ & $\begin{array}{c}5 . \\
\text { Communication } \\
\text { between } \\
\text { physicians and } \\
\text { nurses * }\end{array}$ & $\begin{array}{c}\text { Total } \\
\text { Score of } \\
\text { the } \\
\text { Scale * }\end{array}$ \\
\hline \multicolumn{7}{|l|}{$\begin{array}{l}\begin{array}{l}\text { Length of } \\
\text { service }\end{array} \\
\end{array}$} \\
\hline $\begin{array}{l}\leq 5 \text { years } \\
\mathrm{N}=56\end{array}$ & $2.22 \pm 0.42$ & $2.52 \pm 0.48$ & $2.50 \pm 0.70$ & $1.61 \pm 0.45$ & $2.51 \pm 0.64$ & $\begin{array}{c}2.27 \pm 0 . \\
42\end{array}$ \\
\hline $\begin{array}{l}\text { 6- } 10 \text { years } \\
\mathrm{N}=37\end{array}$ & $2.24 \pm 0.65$ & $2.40 \pm 0.52$ & $2.48 \pm 0.74$ & $1.55 \pm 0.49$ & $2.32 \pm 0.78$ & $\begin{array}{c}2.20 \pm 0 . \\
53\end{array}$ \\
\hline $\begin{array}{l}\text { 11-15 years } \\
\mathrm{N}=32\end{array}$ & $2.05 \pm 0.72$ & $2.05 \pm 0.70$ & $2.09 \pm 0.73$ & $1.39 \pm 0.53$ & $1.97 \pm 0.73$ & $\begin{array}{c}1.91 \pm 0 . \\
60\end{array}$ \\
\hline $\begin{array}{l}16-20 \text { years } \\
N=29\end{array}$ & $2.39 \pm 0.52$ & $2.44 \pm 0.54$ & $2.30 \pm 0.62$ & $1.51 \pm 0.43$ & $2.44 \pm 0.61$ & $\begin{array}{c}2.22 \pm 0 . \\
43\end{array}$ \\
\hline$\geq 21 \mathrm{~N}=20$ & $2.12 \pm 0.56$ & $2.24 \pm 0.49$ & $2.11 \pm 0.56$ & $1.70 \pm 0.44$ & $2.40 \pm 0.62$ & $\begin{array}{c}2.11 \pm 0 . \\
45\end{array}$ \\
\hline $\mathbf{p}$ & 0.184 & 0.003 & 0.033 & 0.155 & 0.010 & 0.018 \\
\hline F & 1.574 & 4.170 & 2.697 & 1.686 & 3.448 & 3.055 \\
\hline
\end{tabular}

* Statistically significant

As seen Table 6, the participants whose length of service varied between 11 and 15 years obtained the lowest mean scores both from the entire scale and from the subscales, in other words they perceived the work environment least positively. Of the participants, those whose length of service was $\leq 5$ years perceived the work environment most positively. There was a statistically significant relationship between the 'length of service' variable and the mean scores obtained from the entire scale and second, third and fifth subscales ( $\mathrm{p}<0.05)$.

According to the analysis, no statistically significant differences were determined between the mean scores the participants obtained from the entire scale and subscales in terms of the variables 'age, marital status, professional title, education level, and monthly income level ( $p>0.05$ ).

Subscales perceived significantly positively in terms of the independent variables are as follows:

Of the participants in the study, those who were the members of a professional organization perceived the "nurses' participation and representation rate in the management" subscale more positively than did those who were not, and the difference was statistically significant ( $\mathrm{p}<0.05)$. Of the participants in the study, those who were males, members of a professional organization, contractual employees and whose length of service was less than 5 years perceived the "nursing foundations needed for quality care" subscale more positively than did those who were females, permanent employees, not members of a professional organization, and whose length of service was more than 5 years, and the difference was statistically significant $(\mathrm{p}<0.05)$.

Of the participants in the study, those who were members of a professional organization, contractual employees and whose length of service was less than 5 years perceived the "managers' attitudes and leadership traits" subscale more positively than did those who were permanent employees, not members of a professional organization, and whose length of service was more than 5 years, and the difference was statistically significant $(\mathrm{p}<0.05)$.

The male participants of the study perceived the "adequacy of workforce and other resources" subscale more positively than did the female 
participants, and the difference was statistically significant $(\mathrm{p}<0.05)$.

Of the participants in the study, those who were the members of a professional organization and whose length of service was less than 5 years perceived the "communication between physicians and nurses" subscale more positively than did those who were not members of a professional organization, and whose length of service was more than 5 years, and the difference was statistically significant $(\mathrm{p}<0.05)$.

\section{DISCUSSION}

A positive work environment is important especially for health care workers' and patient safety. Positive work environments affect all healthcare professionals and improve patient outcomes by promoting the quality of services. ${ }^{33}$. At the end of the present study, the mean score the participants obtained from the "Nursing Work Indexthe Practice Environment Scale" was found to be $\mathrm{X}=2.16 \pm 0.49$.

Based on this result, it can be said that the participants generally perceived the work environment "moderately". In another study conducted at Cumhuriyet University hospital, nurses $(n=159)$ perceived the work environment negatively and $74 \%$ of those nurses considered the working conditions in the workplace as inappropriate ${ }^{29}$. In a study conducted by Kanbay and Üstün, in $2009,50.4 \%$ of the nurses said that they were only partially satisfied with the work environment ${ }^{33}$. In a study conducted by Bostan and Köse, more than half of the participants stated that the work environment was not organized well enough to care about their physical health. ${ }^{24}$ These results partly support the results of the present study. In Mollaoğlu et al.'s and Tan et al.'s studies, nurses perceived the work environment positively. ${ }^{6,34}$ The results of their studies are not similar to those of the present study. This is probably because measuring instruments and characteristics of the sample groups varied form one study to another.
Evaluation of the mean subscale scores revealed that the participants perceived especially the "adequacy of manpower and other resources" subscale negatively ( $\mathrm{X}=1.54$ to \pm 0.47 out of 4 points). At the time the study was conducted, the number of the nurses working in the hospital was 453 , and the number of the beds was 1048 with an occupancy rate of $67.8 \%$. In the light of these data, it can be said that the participants' negative perception of the "adequacy of manpower and other resources" scale was normal due to nursing shortage. Nursing shortage is a worldwide problem (ICN 2007). ${ }^{4}$ In Turkey, according to the "Turkey's Health Education and Health Manpower Status Report (2014)", the number of employed nurses in December 2013 was 149,012 in Turkey. ${ }^{35}$ While $70.3 \%$ of these nurses were employed in the institutions affiliated to the Ministry of Health, $14.5 \%$ were employed in university hospitals. According to the data released by the $\mathrm{WHO}$, the number of nurses per 100,000 people is 836 in EU member countries and 766 in the European countries, but only 197 in Turkey. ${ }^{35}$

Among the causes of the nursing staff shortage in university hospitals are insufficient allocation of nursing staff, high turnover rate because nurses prefer to work in hospitals affiliated to the Ministry of Health due to more intense and exhausting working conditions in university hospitals, and inadequate nurse retention policies and practices of university hospital managements.

In the present study, the participants' mean scores for the other four subscales were slightly higher than the mean total score. While the mean score was $2.20 \pm$ 0.57 for the "nurses' participation and representation rate in the management", it was $2.34 \pm 0.70$ for the "nurse managers' attitudes and leadership traits" and "communication between physicians and nurses" subscales. The mean score for the "nursing foundations needed for quality care" perceived most positively was $2.36 \pm 0.56$. Based on these results, it can be said that the nurses' perception of the hospital in terms of the mentioned subscales was moderate, in other words, 
they did not perceive it positively. In the present study, male participants perceived the work environment more positively than did the female participants (Table 3, p>0.05).

This might be due the fact that men's social roles, expectations and responsibilities are different from those of women. In the present study, $79.9 \%$ were the members of a professional organization and they perceived the work environment more favorably than the other participants. This difference was statistically significant for the whole scale and subscales except for the fourth subscale ( $p<0.005$ ). This result may have been due to the fact that professional organizations support their members, try to solve problems arising in the workplace and protect the rights of their members, and that members of a union or association are in solidarity and thus feel themselves more secure. In a study by Şener et al., ${ }^{36} 62.4 \%$ of the health care professionals participating in their study were the members of a trade union. Of these members, $72.6 \%$ unionized to solve problems arising from the work environment and $24.2 \%$ believed that they might become more powerful through unionizing. These results support the results of the present study.

The contractually employed participants of the present study perceived the work environment more positively than did the permanently employed participants. This difference was statistically more significant for the mean scores obtained from the entire scale and second and third subscales ( $p<0.05$ ). This may have been stemmed from the fact that contractual employees had concerns over losing their jobs and negative responses they gave might cause them to lose their jobs because their job security of was poor.

In the present study, the participants whose length of service was less than 5 years perceived the work environment more positively than did all the other participants (Table 6). This may have been due to fact that their expectations for the work environment and working conditions were lower. Among the other reasons why they perceived the work environment more positively were probably that they had a job and thus were not unemployed, and that they were more idealistic than were senior nurses because they were new in the nursing profession. According to the results of Numminen et al.'s ${ }^{37}$ study, recently graduated nurses perceived the work environment and nurse-physician communication more positively in general, which supported the results of the present study. However, in contrast to the results of the present study, nurses whose length of service was between 6 and 10 years in Tan et al.'s study and nurses whose length of service was $\geq 11$ years in Mollaoğlu's study perceived the work environment more favorably. 6,34

In this study, it was found that the participating nurses assessed the work environment as moderately whereas they perceived the "adequacy of manpower and other resources" subscale negatively. Of the participants in the present study, those who were male, contractual employees and/or members of a professional organization and whose length of service was under 5 years perceived their work environment more positively. No statistically significant differences were determined in the perception of the work environment in terms of the other independent variables.

The nursing workforce both in Turkey and in the hospital where the study was conducted is known to be inadequate. Therefore, the subscale perceived most negatively by the participants was the "adequacy of workforce and other resources" subscale. In this context, it is recommended that the work environment in the hospital should be improved, shortages in workforce and other resources should be eliminated, and points stated in all the subscales of the scale should be improved. That the problems faced in the work environment of nurses are not solved may lead to job dissatisfaction, failure in organizational commitment, work stress and resignations, each of which can bring about undesirable individual and organizational consequences. 


\section{REFERENCES}

1. Saygun M. Sağlık Çalışanlarında İş Sağlığı ve Güvenliği Sorunları. TAF Preventive Medicine Bulletin 2012; 11: 373-82.

2. Özcanarslan N. Hemşirelerin iş ortamındaki stresörlerinin belirlenmesi Çukurova Üniversitesi Sağlık Bilimleri Enstitüsü Hemşirelik Ana Bilim Dalı Yayınlanmamış Yüksek Lisans Tezi 2009 Adana.

3. Dindar İ, İssever H, Özen M. Edirne merkezindeki hastanelerde görev yapan hemşirelerde iş ile ilgili rahatsızlıklar ve konulan tanıla. Hemşirelik Forumu Dergisi 2004; 7 : 59-63.

4. ICN (2007) International NursesDay Information and Action Tool Kit, Positive practice environments: Qualityworkplaces qualitypatientcare, www.icn.ch/indkit2007.pdf

5. Ergüney $S$, Tan $M$, Sivrikaya $S$, Erdem N. Hemşirelerin karşılaştıkları mesleki riskler. Atatürk Üniversitesi Hemşirelik Yüksekokulu Dergisi 2001; 4: 63-73.

6. Tan M, Polat H, Şahin Z. Hemşirelerin çalışma ortamlarına ilişkin algılarının değerlendirilmesi Sağlıkta Performans ve Kalite Dergisi 2012; 67-78.

7. Rafferty AM, Clark SP, Coles J. et al Outcomes of variation in hospital nurse staffing in English hospitals: cross-sectional analysis of survey data and discharge records. Int $\mathbf{J}$ Nursing Studies 2007; 44: 175-82.

8. Clarke SP, Aiken LH. More nursing, fewer death. Qualityand Safety in Health Care 2006: 15: 2-3

9. Aiken LH, Clarke SP, Sloane DM, Sochalski J, Siber JH. Hospital nurse staffing and patient mortality, nurse burnout, and job dissatisfaction. Journal of the American Nursing Association, 2002; 288 (16), 19871993.

10. Baumann A. ICN çeviri metni. Olumlu Çalışma Ortamları 2011. http://www.turkhemsirelerdernegi.or g.tr/Upload/dosyalar/ICN\%20CEVİ Rİ\%20METNİ.do

11. Tourangeau AE, Cranley LA, Jeffs L. Impact of nursing on hospital patient mortality: a focused reviewand related policy implication. Quality\&Safety in HealthCare 2006; 15: 4-8.

12. Karadağ M, Yıldırım N. Hemşirelerde çalışma koşullarından kaynaklanan bel ağrıları ve risk faktörleri. Hemşirelik Forumu 2004; 7: 48-54.

13. Alçelik A, Deniz F, Yeşildal N, Mayda AS, Şerifi BA. AİBÜ tıp fakültesi hastanesinde görev yapan hemşirelerin sağlı sorunları ve yaşam alışkanlıklarının değerlendirilmesi, TSK Koruyucu Hekimlik Bülteni 2005; 4: 55-66.

14. Parlar S. Sağlık çalışanlarında göz ard1 edilen bir durum: sağlıklı çalışma ortamı. TAF Preventive Medicine Bulletin. 2008; 7: 547-54.

15. ILO. Terms of employment and working conditions in health sector reforms. www.ilo.org.

16. Çetin G. Hastanelerde çalışan hemşirelerin olumlu iş ortamına ilişkin görüşlerinin belirlenmesi. Sağlı Bilimleri Enstitüsü Yüksek Lisans Tezi 2008.

17. Karadağ M, Yildırım N. Hemşirelerde çalışma koşullarından kaynaklanan bel ağrıları ve risk faktörleri. Hemşirelik Forumu 2004; 7: 48-54.

18. Karadağ S, Taşçı S. Kayseri Devlet Hastanesinde çalışan hemşirelerin verdiği hemşirelik bakımı ve bakımı etkileyen faktörler. Sağlık Bilimleri Dergisi 2005; 14 (Ek Say1: Hemşirelik Özel Sayısı), 13-21.

19. Uğur $\mathrm{E}$, Abaan $\mathrm{S}$. Hemşirelerin iş yaşamı kalitesi ve etkileyen faktörlere ilişkin görüşleri. Türkiye Klinikleri 2008; 28: 297-310.

20. Yaprak E, Seren Ş. Hemşirelerin işten ayrilma niyetleri ve örgüt ikliminin hemşire istihdamına etkisi. 
Hemşirelikte Eğitim ve Araştırma Dergisi 2010; 7: 28-33.

21. Türkmen E, Badır A, Balcı S, Topcu SA. Hemşirelik iş indeksi-hemşirelik çalışma ortamını değerlendirme ölçeğinin Türkçe'ye uyarlanması: güvenilirlik ve geçerlilik çalışması" Hemşirelikte Araştırma Geliştirme Dergisi 2011; 2, 5-20.

22. Turkish Nurses Association 7 Gün24 Saat/ Hasta Başında Türkiye'de Hemşirelerin Çalışma Koşulları, 2008 Ankara.

23. Duygulu S, Aban S. Örgütsel bağlılık: Çalışanların kurumda kalma ya da kurumdan ayrılma kararının bir belirleyicisi. Hacettepe Üniversitesi Hemşirelik Fakültesi Dergisi; 2007: 61-73.

24. Bostan S, Köse, A. Hemşirelerin yönetsel hizmetleri ve çalışma ortamlarını değerlendirmesi-bir üniversite hastanesi örneği. Marmara Üniversitesi Sağlık Bilimleri Enstitüsü Dergisi 2011; 1: 178-83.

25. Polatkan R. Sabancioğulları S, Taşkın F ,Gözübüyük E. hemşirelerin iş gücü devir hızı ile işte kalma ve işten ayrılma niyetlerine etki eden faktörlerin incelenmesi: sivas ili örneği. 6. Uluslararası Hemşirelik Yönetimi Kongresi 2014, Muğla.

26. Mert VR. İş Sağlığı ve Güvenliği Hizmetlerinde Yeni Hedefler. İşveren 2002; Mayıs, XL: 8.

27. Lowe G. High-Quality healthcare workplaces: A vision and action plan. Hospital Quarterly 2002; Summer 49-56 http://www.grahamlowe.ca/docume nts/23/HQ54GLowe.pdf

28. Sezgin B. Kalite belgesi alan hastanelerde çalışma ortamı ve hemşirelik uygulamalarının hasta ve hemşire güvenliği açısından değerlendirilmesi. 2007, İ.Ü. Sağlik Bilimleri Enstitüsü Hemşirelikte Yönetim Anabilim Dal1, Doktora Tezi.

29. Ulusoy H, Aydın Ş. Bir üniversite hastanesinde çalışan hemşirelerin çalışma ortamına ilişkin görüşlerinin belirlenmesi. VIII. Ulusal Sağlık Kuruluşları Yönetimi Kongresi, MArmaris, Bildiriler Kitabı 2010; 334-1.

30. Sağlık Bakanlığı Sağlık Kurum Ve Kuruluşlarında Hasta Ve Çalışan Güvenliğinin Sağlanması Ve Korunmasına İliş̧kin Usul Ve Esaslar Hakkında Tebliğ. Resmi Gazete, 29 Nisan 2009.

31. Tüzüner VL, Özaslan BÖ. Hastanelerde iş sağlı̆̆g ve güvenliği uygulamalarının değerlendirilmesine yönelik bir araştırma. İstanbul Üniversitesi İşletme Fakültesi Dergisi 2011; 40: 138-54.

32. Lake ET. Development of the practice environment scale of the work index. Research In Nursing \& Health 2002; 25: 176-88.

33. McGirr M, Bakker DA. Shaping Positive work environments for nurses: the contributions of nurses at various organizational levels. Can J Nursing Leadership 2000; 13: 7-14.

34. Kanbay, Y, Üstün B. Kars ve Artvin illerinde hemşirelerin iş ortamı ile ilgili stresörleri ve kullandıkları başetme yöntemlerinin incelenmesi. Dokuz Eylül Üniversitesi Hemşirelik Yüksekokulu Dergisi 2009; 2: 15561.

35. Mollaoğlu M, Fertelli TK, Tuncay FÖ. Hastanede Çalışan Hemşirelerin Çalışma Ortamlarına ilişkin Algılarının Değerlendirilmesi”, Fırat Sağlık Hizmetleri Dergisi, 2010; 515.

36. Şener E, Balci H, Şarlak K. Sağlık çalışanlarının mesleki sendikal ve sivil örgütlenme durumları. VIII. Ulusal Sağlık Kuruluşları Yönetimi Kongresi sözel bildiri kitab1 2010.

37. Numminen $O$, Ruoppa E, LeinoKilpi H, Isoaho H, Hupli M, Meretoja R. Practice environment and its association with professional competence and work-related factors: perception of newly graduated nurses. J Nursing Management 2016; 24: 1. 